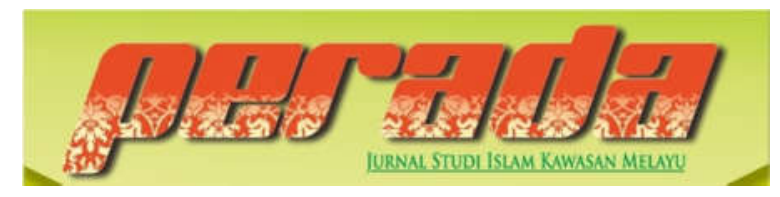

\author{
Perada: Jurnal Studi Islam Kawasan Melayu \\ ISSN 2656-7202 (P) ISSN 2655-6626 (0) \\ Volume 4 Nomor 2, Juli-Desember 2021 \\ DOI: https://doi.org/10.35961/perada.v4i2.396
}

\title{
PEMIKIRAN ETIKA SUFISTIK MENURUT AL-GHAZALI DALAM KITAB MINHAJ AL-‘ABIDIN
}

\author{
Aminudin \\ IAIN Sultan Amai Gorontalo \\ aminudin@iaingorontalo.ac.id
}

\begin{abstract}
ABSTRAK
Tulisan ini membahas tentang konstruksi ataupun konsep tentang etika sufistik yang terdapat dalam salah satu karya al-Ghazali dalam kitab yang berjudul Minhaj al-'Abidin. Penelitian ini bertujuan untuk mengungkapkan dengan jelas bagaimana sebenarnya ajaran etika tasawuf (etika sufistik) al-Ghazali terutama yang terdapat dalam kitab Minhaj al-'Abidin. Metode yang digunakan adalah metode deskriptif analitis, yaitu penulis memberikan gambaran dan menganalisis nilai-nilai atau dimensi-dimensi etika sufistik yang terkandung dalam kitab Minhaj al-'Abidin. Penelitian ini berbasis pustaka (library research). Hasil penelitian menyimpulkan bahwa konsep etika sufistik yang dikemukakan oleh al-Ghazali dalam kitab Minhaj al-'Abidin tentang anjuran untuk mengendalikan hawa nafsu dan taubat sebagai jalan menuju Allah Swt. Etika sufistik yang digagas oleh al-Ghazali menjadi kajian yang sangat unik dan menarik ketika di gunakan untuk melihat kondisi kekinian di Indonesia, melihat keterpurukan yang kian melanda disekitar kita tentang etika. Sehingga kajian ini menjadi alat pembantu untuk sedikit menyelesaikan permasalahan-permasalahan yang dialami bangsa.
\end{abstract}

This paper discusses the construction or concept of sufistic ethics contained in one of alGhazali's works in the book entitled Minhaj al-'Abidin. This research aims to express clearly how exactly the teachings of sufism (sufistic ethics) al-Ghazali are mainly found in minhaj al-'Abidin. The method used is an analytical descriptive method, i.e. the author provides an overview and analyzes the values or dimensions of sufistic ethics contained in the book Minhaj al- 'Abidin. This research is library research. The results of the study concluded that the concept of sufistic ethics expressed by al-Ghazali in minhaj al-'Abidin is about the advice to control lust and repentance as the way to Allah. Sufistic ethics which was initiated by al-Ghazali becomes a very unique and interesting study when it is used to see the current conditions in Indonesia, seeing the downturn that is increasingly engulfing us about ethics. So that this study becomes a supporting tool to solve some of the problems experienced by the nation.

Kata Kunci: Al-Ghazali, Minhaj al-'Abidin, Etika Sufistik. 


\section{PENDAHULUAN}

Pada akhir-akhir ini, fenomena keter-purukan atau krisis moral yang terjadi kini sudah semakin akut dan mengkhawatirkan. Sehingga manusia pada giliranya banyak dibenturkan oleh problem-problem kehi-dupan. Sebagai salah satu imbas dengan adanya perkembangan ilmu pengetahuan dan teknologi (IPTEK) yang semakin pesat mengakibatkan merosotnya nilai-nilai etika. Di satu sisi, dunia global yang dihadapi masyarakat modern menyebabkan bergesernya nilai-nilai tradisi masyarakat dengan norma-norma sosial sehingga memunculkan dekadensi moral terjadi dimana-mana, mulai dari tatanan tingkat atas sampai tatanan yang paling bawah.

Islam, sesungguhnya memiliki pandangan yang memposisikan manusia sebagai entitas material sekaligus spiritual. Artinya manusia terbentuk dari unsur material dan spiritual yang terpadu secara harmonis. Menghilangkan dimensi spiritual itu akan berdampak pada kesengsaraan manusia itu sendiri, dengan kata lain hidup akan terasa hambar ketika tidak menyeimbangan dengan kesadaran spiritual tersebut. Ironisnya, kebanyakan manusia lebih tertarik kebutu-han materialnya dibanding kebutuhan sritualnya.

Al-Ghazali ${ }^{1}$, persoalan etika tidak dapat dianggap sebagai persoalan sepele,

1 Nama Abu Hamid berasal dari nama seorang putranya, yakni Hamid. Oleh sebab itu, ia panggil Abu Hamid (ayahnya Hamid), meskipun anak tersebut meninggal sewaktu masih kecil. Sementara sebutan al-Ghazali berasal dari dua kemungkinan, pertama: nama tersebut di ambil dari nama tempat kelahirannya yaitu Ghazalah, yakni suatu kampung kecil yang berada dikabupaten Thus, propinsi Khurasan, wilayah persi (Iran) oleh karena itu, sebutan al-Ghazali dengan satu "Z", Kedua; nama tersebut berasal dari pekerjaan seharihari yang dihadapi dan dikerjakan oleh ayahnya, sebagai seorang penenun dan penjual kain tenun yang dinamakan gazzal oleh sebab itu, sebutan alGhazzali dengan dua " $Z$ ". Lihat, Zainal Abidin melainkan persoalan yang sangat penting dan niscaya, dan juga sangat berpengaruh sekali akan ketentraman hidup di dunia. Karena kedudukan etika dalam kehidupan manusia menempati tempat yang penting, baik sebagai individu maupun masyarakat bangsa, sebab jatuh bangunnya suatu masyarakat tergantung kepada bagaimana akhlaknya, apabila akhlaknya baik, maka sejahteralah lahir dan batinnya, akan tetapi apabila akhlaknya rusak, maka rusaklah lahir dan batinnya. ${ }^{2}$

Berangkat dari fenomena-fenomena keterpurukan moral tersebut, maka penulis tertarik mengangkat tokoh yaitu alGhazali, beliau dikenal sebagai seorang teolog, filosof, dan sufi dari aliran Sunni, terutama dalam permasalahan akhlak atau etika, baik kaitannya dengan mu'amalah dalam masyarakat secara filosofis teoritik dan aplikatif. Penulis juga memberikan rumusan masalah dalam artikel ini yaitu: Pertama, bagaimana konsep etika sufistik yang termaktub di dalam kitabnya yang berjudul Minhaj al Abidin, dan kedua, bagaimana relevansinya terhadap perkembangan dunia modern saat ini.

\section{IDENTIFIKASI KITAB MINHAJ $A L-' A B I D I N$}

Judul lengkap kitab ini, seperti yang telah disusun oleh pengarangnya sendiri, ${ }^{3}$ adalah Minhaj al-Abidin ila al-Jannah (jalan para ahli ibadah menuju surga). Namun demikian judul yang tertulis didalam covernya adalah Minhaj al-Abidin (baca: Minhaj al-Abidin) saja, sehingga judul inilah yang kemudian menjadi poluler. Kitab ini merapakan karya terakhir al-Ghazali dan hanya didiktekan kepada murid-muridnya yang telah encapai tingkatan tertentu.

Ahmad, Riwayat al-Ghazali (Jakarta: Bulan Bintang, 1975), hlm. 27-28.

2 M. Yatimin Abdullah, Studi Akblak dalam Perspektif Al-Qur'an (Jakarta: Amzah, 2007) , hlm.1.

3 Imam al-Ghazali, Minhaj al-Abidin (Dar Kutub al-Arabiyyah, Indonesia tt), Hlm. 5. 
Kitab Minhaj al-Abidin yang sedang diteliti ini ditulis atas pendiktean langsung dari alGhazali, oleh salah seorang muridnya yaitu al-Syaikh a-Faqih al-Shalih al-Zahid Abd al-Malik.

Pentingnya kitab ini bisa dilihat dari alasan penyusunannya sendiri, yaitu bahwa beliau tidak pernah menulis kitab dengan sistematika yang sangat menarik dan lebih baik dibanding kitab ini. Bisa dikatakan bahwa kitab ini merupakan rangkuman dari sekian banyak karya yang ditulis oleh al-Ghazali berkenaan dengan ilmu-ilmu akhirat, atau lebih tepatnya ilmu-ilmu tentang jalan ibadah. Jalan yang dimaksudkan adalah jalan yang bersifat bathiniyah.karena jalan yang bersifat lahiriyah lebih bnyak dibicarakan oleh ilmu fiqh (ahli fuqaha') dan ilmu kalam (para mutakallimin).

Karena statusnya yang sedemikan penting, maka tidak berlebihan bahwa alGhazali sendiri menilai kitab ini lebih unik disbanding dengan kitab Ibya' Ulum al-Din, karya yang dianggap oleh banyak pihak sebagai karya terbesarnya. Barangkali keunikannya terletak pada sistematikanya yang sedemikan jelas dan tegas, meskipun untuk menapakinya diperlukan keilmuan dan praktik yang memadai. Itulah sebabnya kitab ini didiktekan oleh alGhazali hanya untuk murid-murid pilihannya.

Berdasarkan cetakannya, kitab ini ditulis bersamaan dengan kitab Bidayah alBidayah, sebuah karya lain al-Ghazali yang diangap oleh banyak penulis sebagai karya pengantar bagi para salik (penempuh jalan ruhaniyah). Sedang kitab Minhaj al-Abidin ditulis dibagian tengahnya secara penuh. Kedua kitab ini sama-sama ditulis dengan bahasa arab tanpa harakat (gundul dalam bahasa jawa).

Penulis kitab ini sudah sangat popular. Sedemikian populernya sampaisampai dikatakan bahwa orang islam yang paling populer sesudah Nabi Muhammad
SAW adalah al-Ghazali. ${ }^{4}$ Sudah banyak karya yang disusun mengenai dirinya dan pemikiran-pemikiranya, mulai dari yang pro ataupun yang kontra. Umumnya yang mengkritiknya mengatakan bahwa ia telah menyebelih sendiri ayam yang bertelur emas. Maksudnya ia telah membunuh filsafat yang selama ini ditekuni bidang baru yaitu tasawuf atau sufisme. Namun bagi yang pro yang dilakukan al-Ghazali bukanlah membunuh ayam yang bertelur emas, melainkan merupakan sebuah fase perjalanan intelektual dan spiritual yang harus dijalani oleh seseorang. Itu sebabnya, Zurkhani Yahya menstrukturkannya sistem pemikirinya dengan sebuah teologi yang utuh. ${ }^{5}$

Jika dikaitkan dengan tiga varian utama ilmu keislaman, yaitu fiqih, ilmu kalam, dan tasawuf. Lebih tepatnya tasawuf 'amaily. Yakni tasawuf yang lebih banyak berbicara tentang bagaimana melakukan ibadah dengan baik agar mencapai tujuannya, yakni berada sedekat mungkin dengan Tuhan. Karena termasuk tasawuf amaliy, maka kitab ini dikategorikan dengan sebagai kitab akhlak. Tepatnya kitab tentang pendidikan akhlak. Paradigmanya adalah bahwa moralitas harus dibangun atas dasar kesadaran ketuhanan yang kuat. Moralitas yang tidak didasarkan pada keasdaran ketuhanan sesungguhnya hanya moralitas semu. Kitab Minbaj al-Abidin ini antara lain bertujuan untuk membangun moralitas melalui pembangunan kesadaran ketuhanan yang kuat atau dalam istilah al-Ghazali jalan ibadah menuju surga.

\section{ETIKA SUFISTIK DALAM KITAB MINHAJ AL-'ABIDIN}

\section{a. Meninggalkan hawa nafsu untuk menuju Allah Swt}

\footnotetext{
${ }^{4}$ Nurcholis Madjid (ed), Khazanah Intelektual Islam (Jakarta: Bulan Bintang, 1994), hlm. 33.

5 Zurkani Yahya, Teologi al-Ghazali: Pendekatan Metodologi, (Yogyakarta: Pustaka Pelajar, 1996), hlm. 63.
} 
Al-Ghazali memulainya dengan pendefinisian hawa nafsu terlebih dahulu. Bahwa kata kata nafs juga mengandung beberapa makna (jiwa, suka, diri, nafsu, dan sebagainya). Namun, yangbberkaitan dengan pebahasan ini hanya ada dua macam. Pertama, mencakup fakultas emosi atau amarah dan ambisi atau hasrat (syahwat) dalam diri manusia, sebagaiamana yang akan diuraikan kemudian. Para ahli tasawuf mengartikan nafsu mencakup berbagai sifat-sifat tercela pada diri manusia. Kedua, kata nafs adalah serupa dengan satu makna hati, sesuatu yang abstrak yang membentuk diri manusia sendiri secara hakiki. ${ }^{6}$ Istilah nafsjuga mempunyai dua pengertian. Pertama, nafsu adalah nafsu atau diri yang lebih mendasar atau lebih rendah kedudukannya mencakup penegrtian hawa nafsu, amarah, dan sifat-sifat jahat lainnya. Kedua, istilah nafsu adalah jiwa atau hati. Dikala nafsu mencapai ketenangan dan telah berhasil menyingkirkan hawa nafsunya.

Nafsu adalah substnasi yang berdir sendiri, tisak bertempat, serta merupakan tempat bersemayam pengetahuanpengetahuan intelektual yang berasal dari alam al-Malakut atau alam al-amr. Nafsu memiliki daya sebagai irivasinya dan atas dasar tingkatan-tingkatan daya tersebut, pada diri manusia. ${ }^{7}$ Hawa nafsu ini merupakan penghalang seseorang melakukan ibadah. ${ }^{8}$ Untuk itu, kita harus berhati-hati terhadap dorongan hawa nafsu yang akan menyeret kita berbuat kejahatan. Hawa nafsu adalah musuh yang sangat mencelakakan dan juga menmbulkan petaka yang amat besar dan sukar dihindari. Oleh karena itu, kita harus waspada. Ini karena dua perkara, yaitu:

6 Al-Ghazali, Keajaiban-keajaiban Hati (Bandung: Kanisius, 2000), hlm. 28.

7 Amin Syukur, Masharuddin, Intelektualisme Tasawnf, Studi Intelektualisme Tasawnf al-Ghazali (Yogyakarta: Pustaka Pelajar, 2002), hlm. 171.

8 Al-Ghazali, Terjemah Minhaj al-'Abidin Petunjuk Abli Ibadah (Surabaya: Mutiara Ilmu, 1995), hlm. 117.
Pertama, hawa nafsu merupakan musuh dari dalam. Bukan musuh dari luar. Seperti halnya setan. Benar yang dikatakan alGhazali yang ditertuang dalam syairnya dalam kitab Minhaj al'Abidin:

"Nafsu senantiasa mengajakku ke jalan celaka, hingga aku merasa sakit dan nyeri. Bagaimana seharusnya aku bertindak, jika musub itu menyelinap diantara tulang rusukku',

Dikandung maksud bahwasanya nafsu itu adalah bagaiakan seseorang yang mengendarai kuda sembari memimpin anjing untuk berburu dihutan. Jikalau seseorang baik dalam melatih kudanya dan anjingnya, maka dia akan hidup dalam kesejahteraan dan penuh kebajikan serta dapat melakukan fungsi hidupnya secara baik, meskipun keduanya terkadang mogok ataupun lari tak terkendali. ${ }^{10}$

Demikian pula seandainya seseorang tidak bisa mengenali nafsunya, maka dalam hidupnya akan selalu tersesat. Sebaliknya jika seseorang bisa mengendalikan nafsunya dengan baik atau dengan ibarat seorang kusir bisa mengendarai kuda dengan baik, maka yang terjadi adalah akan terasa lebih nyaman dan melakukan fungsinya dengan baik dan berhati-hati. Para sufi menjelaskan apa yang dimaksud hawa nafsu dengan menerangkan struktur kepribadian kita. Dalam setiap diri kita, kita selalu menemukan beberapa kekuatan yang mebdorong kita untuk melakukan sesuatu. Psikologi barat menyebutnya motive. Para sufi menyebutnya dengan kekuatan-kekuatan hawa nafsu.

Paling tidak, ada tiga kekuatan hawa nafsu dalam diri kita ${ }^{11}$; pertama, disebut dengan Quwwatun Babimiyyah (kekuatan kebinatangan). Dalam diri kita terkandung

${ }^{9}$ Imam al-Ghazali, Minhaj al-Abidin (Dar Ihya'i al-kutub al-Arabiyyah, Indonesia tt), hlm. 24.

10 Sudin, Filosof Etika dan Sosial Islam Ibn Miskawaih (Yogyakarta: SUKA-Press, 2012), hlm. 7-8.

11 Jalaluddin Rakhmat, Meraib Cinta Ilabi (Bandung: Rosda Karya, 2000), hlm. 4. 
unsur-unsur kebintangan. Unsur inilah yang medorong kita untuk mencari kepuasan lahiriyah atau kenikmatan seksual. Kekuatan yang kedua adalah Qumwatun Ab'iyah (kekuatan binatang buas). Kita sering menyerang orang lain. Kita suka memakan hak orang lain. Kita ingin membenci, menyerang, menghancurkan atau bahkan sampai menganiaya diri sendiri dan orang lain disekitarnya.

Kita juga mempunyai satu kekuatan lain dalam diri kita yang disebut Qumwatun Syaithaniyyah. Inilah kekuatan yang mendorong kita untuk membenarkan segala kejahatan yang kita lakukan. Kalau kita mengabil hak orang lain. Setan membisikan dalam hati kita agar kita tidak usah merasa bersalah sebab kita mengambil hak orang lain untuk dipergunakan membantu saudara-saudara kita. Mungkin kita mengatakan ini adalah contoh dari berbuatan jahat yakni yang disebut korupsi. Dia seakan-akan mengatakan akan hidup selama-laanya dengan memakan harta orang lain dengan cara yang tidak diperbolehkan oleh agama dan hukum yang berlaku. Ketiga kekuatan itu berasal dari hawa nafsu.

Namun Tuhan juga enyimpan dalam diri kita sebagao satu bagian penting dari kepribadian kita. Satu percikan cahaya Tuhan. Itulah yang dimaksud dengan Quwwatun Rabbaniyyah (kekuatan Tuhan). Kekuatan ini terletak pada akal sehat atau akal yang salim. Apabila keingingan untuk mengejar hawa nafsu itu menguasai diri kita, maka kita sebenarnya binatangbinatang secara rubaniyah. Walaupun secara jasmaniyyah, kita menampakan seperti manusia.

Apabila senang memeilihara dendam, perasaan iri hati, kejengkelan, kemarahan dalam hati kita, kita adalah serigala-serigala yang buas/jahat. Apabila dalam diri kita yang berkuasa adalah kepandaian mencari dalih dan alasan untuk membenarkan kekeliruan-kekeliruan kita.
Secara hakikat kita sebenarnya adalah setan yang mempunyai penampilan yang menyerupai manusia. Sebaliknya, bila akal menundukan ketiga-tiganya, kita akan dibimbing akal untuk menempuh perjalanan ruhani menempuh Allah Swt. Tugas akal adalah mengendalikan seluruh hawa nafsu secara totalitas, dengan cara itulah, kita dapat mendekati Allah dan mencapai sepenuh-penuhnya taubat.

Marilah kita berusaha menaklukan hawa nafsu kita dan meletakkan akal sehat diatas ketiga kekuatan yang berasal dari hawa nafsu itu. Hnya dengan itu, kita akan berlayar menuju Allah Swt, menghampiriNya, dan melepaskan kerinduan kita kepada-Nya. Orang mukmin mendapatkan kebahagiaan sempurna baik ruhani maupun jasmani. Bila diteliti tingkatantingkatan keutamaan kebahagiaan itu, tingkatan-tingkatannya mirip tingkatannya para ahli tasawuf (sufi), dimana dimulai dari taubat, maka sikap tawakal (inabah) itu bertingkat dalam maqam-maqam (tasawuf), sehingga manusia dapat mencapai tingkatan Rabbani dan hilanglah kepribadian dalam mecintai Allah dan taat kepada-Nya.

\section{b. Taubat sebagai jalan menuju Allah Swt}

Sebelum membahas lebih lanjut, perlu dijelaskan arti taubat terlebih dahulu. Dalam bahasa arab, ada beberapa kata untuk menunjukan kata"kembali". Kata yang paling ketahui adalah kata id atau $a u$. Berasal dari kata 'ada-ya 'uduyang artinya kembali. ${ }^{12}$ Sebagian orang mengatakan bahwa idul fitri artinya kembali kepada fitrah. ${ }^{13}$

Paling tidak ada dua alasan kita sebagai orang-orang yang menjalankan ibadah untuk melakukan taubat:

12 Jalaluddin Rakhmat, Meraih Cinta Ilabi (Bandung: Rosda Karya, 2000), hlm.23.

${ }^{13}$ Ada juga yang engatakan fitr disitu berasal dari kata futhur sehingga Idul fitri diartikan kembali kepada kegiatan makan siang hari seperti biasa. 
Pertama, agar kita taat. Sebab, perbuatan dosa mengahalangi perbuatan taat dan mengahalangi ketauhidan, berkhidmat kepada Allah Swt dan mengahalangi kita untuk berbuat kebajikan. Ketika secara terus menerus berbuat dosa membuat hati menjadi hitam, dan hatipun menjadi keras. Tidak ada kebersihan dan kejernihan, tidak akan ikhlas dan senang dalam beribadah. Jika Allah tidak memberikan rahmat, maka hati yang demikian itu akan menjerumuskan kedalam kekufuran dan kecelakaan. ${ }^{14}$

Sungguh ironis, bagaimana orang akan taat, sedangkan hatinya keras. Bagaimana akan berhidmat jika terus menerus berbuat maksiat dan sombong. Bagaimana akan menghadap Allah, jika selalu berlumuran dosa dan noda. Oleh karena itu, tidak mengherankan jika seseorang selalu berbuat maksiat tidak akan mendapatkan taufik. Sehingga, anggota badannyamerasa berat untuk menjalankan ibadah kepada Allah. Jika kebetulan menjalankannya, ia merasakan kesusahan, tidak dengan perasaan senang dan ikhlas. Hal itu disebabkan karena dosanya dan meninggalkan taubat. Benar jika ada yang mengatakan, jika tidak mampu mengerjakan shalat malam dan puasa, menandakan bahwa ia terbelunggu oleh dosanya. ${ }^{15}$

Jadi, bagi orang yang tidak mau bertaubat maka orang tersebut sombong dan merasa diri tidak mempunyai kesalahan baik pada dirinya, pada Allah dan pada orang lain disekitarnya. Jelas dia tidak termasuk orang yang mendapatkan taufik (pertolongan) dari Allah Swt baik di dunia maupun diakhirat. Kita tahu bahwa sesungguhnya Allah Swt maha pengampun dan Maha Penerima taubat.

Ketika menjelaskan ini, al-Ghazali memulaianya dengan pendefinisian taubat. Menurut al-Ghazali taubat merupakan awal perjalanan para penempuh dan

${ }^{14}$ Ibid.,Minhaj al-'Abidin, hlm. 9.

${ }^{15}$ Ibid.,Minhaj al-'Abidin, hlm. 10. merupakan kunci kebahagiaan para pengharap hadirat Allah. ${ }^{16}$ kemudian dia mengawali dengan dasar al-Qur'an:

"Sesunggubnya Allab menyukai orangorang yang bertaubat dan menyukai orang-orang yang mensucikan diri". (Q.S. al-Baqarah: 222)

"Dan bertaubatlah kamu sekalian kepada Allah, Hai orang-orang yang beriman supaya kamu beruntung". (Q.S. An-Nur: 31)

Kedua, agar ibadah kita diterima oleh Allah Swt. Kerena taubat merupakan inti dasar untuk diterimanya ibadah, dan kedudukan ibadah seolah-olah hanya sebagai tambahan. Ibarat orang yang memberikan pinjaman, ia tidak akan mau menerima bunganya, jika hal pokoknya tidak dipenuhi. Jadi, bagaimana mungkin kebaikan kta akan diterima jika pokonya tidak kita kerjakan?! Bagaimana mungkin akan menjadi baik bila kita meninggalkan yang halal dan mengubah yang mubah, serta tidak henti-hentinya megerjakan yang haram. Bagaimana akan menjadi baik jika kita bermunajat dan berdosa serta memuji Tuhan, sedangkan Tuhan murka kepada kita dikarenakan kita selalu mengerjakan yang menjadikan Allah murka. Demikianlah keadaan orang yang yang enggan meninggalkan perbuatan maksiat. Semoga Allah memberikan pertolongan kepada kita dalam bertaubat. ${ }^{17}$

Esensi taubat adalah kembali dari jalan yang jauh menuju jalan yang dekat. Namun demikian taubat yaitu mempunyai pilar, prinsip dasar dan kesempurnaan. Prinsip dasar itu adalah iman. Yang berarti terpancarnya cahaya ma'rifat pada kalbu sehingga dosa-dosa yang ada didalamnya meniupkan racun yang membinasakan. Dari sana bara rasa takut (khauf) dan penyesalan (nadam), kemudian dari bara inilah memancarkan sikap waspada dan sikap memperbaiki kekeliruan. ${ }^{18}$

16 Al-Ghazali, Teosofia al-Qur'an (Surabaya: Risalah Gusti, 1995), hlm. 209.

${ }^{17}$ Ibid., Minhaj al-'Abidin, hlm. 10.

${ }^{18} \mathrm{Ibid}$, Teosofia al-Qur'an, hlm. 210. 
Berkata guru kami, bahwa taubat adalah meninggalkan dosa yang telah diperbuat dan dosa-dosa yang sederajat dengan itu, dengan mengagungkan Allah dan takut akan murka-Nya Allah Swt.

Adapun syarat taubat ada empat yang dijelaskan oleh al-Ghazali dalam kitab Minhaj al-'Abidin, yaitu di antaranya:

1. Meninggalkan dosa dengan sekuat hati dan niat. Tidak akan mengulangi perbuatan dosa yang pernah dilakukan. Jika terdapat kemungkinan pada suatu saat akan mengerjakan kembali, maka belum dapat dikatakan bertaubat. Demikian juga tidak ada kepastian dalam niatnya, hatinya ragu untuk menghentikan perbuatan dosa, mengehntikan dosa hanya sementara, maka belum dapat dikatakan bertaubat.

2. Menghentikan atau meninggalkan perbuatan dosa yang pernah dilakukannya, itu adalah menjaga, bukan bertaubat. Contoh, tidak benar jika dikatakan bahwa Nabi bertaubat dari kekufuran, sebab Nabi Muhammad Saw, tidak pernah kufur. Yang tepat Nabi menghindari kufur. Tetapi terhadap Umar r.a., tepat jika dikatakan Sayyidina Umar r.a taubat dari kekufuran, karena beliau telah meninggalkan perbuatan-perbuatan jahiliyah.

3. Perbuatan dosa yang pernah dilakukannya harus setimpal atau seimbang dengan dosa yang ditinggalkan sekarang. Misal ada seorang kakek-kakek yang memang dulunya bebuat zina dan penyamun. Karena sudah tua, ia tidak mampu lagi melakukan perbuatan-perbuatan itu. Meskipun ia masih ingin melakukannya. Merasa tidak mampu lagi melakukannya, maka ia taubat. Jadi cara bertaubat adalah meninggalkan dosa yang setimpal dengan dosa pezina dan penyamun. Yakni dosa-dosa (yang meskipun ia sudah tua) namun masih mampu melakukannya.
4. Meninggalkan semata-mata untuk mengagungkan Allah Swt bukan karena yang lain. Tetapi takut akan murka Allah, serta takut akan hukumanhukuman-Nya yang pedih. Tidak ada maksud keduniaan, tidak takut kepada orang lain, juga bukan takut dipenjarakan. Jika taubat karena hanya takut dipenjara, berarti ia bertaubat kepada penjara, buka terhadap Allah Swt. ${ }^{19}$

Jadi taubat adalah semata-mata takut akan murka Allah. Bukan takut dipenjarakan atau bukan karena tidak mempunyai uang. Tetapi jika ia punya uang akan melakukan lagi, dan sebagainya.

Itulah syarat-syarat taubat dan rukun-rukunnya. Apabila keempat syarat tersebut berhasil diamalkan, maka itulah taubat yang sejati dan sesungguhnya. Dan itulah yang dimaksudkan dalam al-Qur'an dengan taubatan nasuba.

Menurut al-Qur'an, hati kita mempunyai lampu fitrah yang membawa kita kepada kesucian dan kerinduan kepada Allah Swt. Kita ini berasal dari Dia. Jauh dari lubuk hati yang paling dalam, yang kita sebut fitrah, ada kerinduan kita kepada-Nya. Tetapi, kerinduan itu kita sering lupakan. Mungkin kita tersepona dengan tempat yang baru ini, dunia; seperti halnya ketika itu sedang merantau keluar negeri untuk yang pertama kali. Karena kehidupan yang senang kita tidak ingat untuk kembali.

Kalau orang itu mendapat musibah, biasanya ia kembali kepada Allah Swt. Karena itu, Nabi bersabda kepada orang yang mengeluh karena musibah," sesunggubnya tidak ada baiknya orang yang tidak pernah mendapat musibab". Kalau mendapat musibah, orang biasanya kembali kepada Allah Swt. Jadi, musibah itu bagus kalau mengembalikan kita kepada fitrah. Dengan musibah kita mengalami idl fitri sejati, idul fitri yang

${ }^{19}$ Ibid.,Minhaj al-'Abidin, hlm. 10-11. 
sebenarnya. Kita kembali membersihkan misykat hati kita, dan mulailah perlahanperlahan cahaya Ilahi itu keluar.

Al-Qur'an juga bercerita tentang yaqzhah atau kembali kepada fitrah ini dengan menggambarkan orang yang berada didalam perahu. Ketika perahu berada ditengah lautan, lalu dating badai yang mengambing-ambingkan perahu itu. Saat itu semua kembali kepada fitrahnya yaitu berdoa kepada Allah denagn Ikhlas.

Dari yaqzah, orang meningkat kepada taubat, maqam yang kedua, dari taubat, naik kepada makam yang ketiga yaitu mubasabah. Setelah maqam mubasabah, barulah maqam inabah ${ }^{20}$. Yang kita bicarakan adalah taubah dan inabah. Kembali kepada kata taubat. Istilah lain untuk taubat adalah istighfar. Ketika kita beristighfar, kita berarti memohon ampunan kepada Allah agar dijauhkan dari dosa-dosa. Dalam bahasa arab akibat dosa itu adalah disebut tabi'ah yang artinya akibat-akibat buruk dari sesuatu.

Istighfar adalah memohon agar Allah Swt memelihara kita dari akibat dosa-dosa. Oleh karena itu, dalam al-Qur'an disebutkan, Allah tidak akan menurunkan adzab kepada mereka selama mereka beristighfar. Karena itu, perbnyaklah istighfar supaya akibat-akibat dosa tidak menimpa kita. Nabi Saw saja sering beristighfar sampai tujuh puluh kali. Dalam riwayat lain disebutkan beliau membacanya seratus kali. Maka kita seharusnya paling tidaknya beristighfar kepada Allah, memohon kepada-Nya agar supaya akibat-akibat dari dosa kita tidak berlanjut.

Berangkat dari konsep tersebut diatasketika digunakan untuk memahami pemikiran al-Ghazali tentang etika sufistik dalam kitab Minhaj al-Abidin. Maka ditemukan suatu pemikiran bahwa dimensi-dimensi sufistik yang terdapat di dalam kitab tersebut; yang pertama anjuran

${ }^{20}$ Jalaluddin Rakhmat, Meraih Cinta Ilahi (Bandung: Rosda Karya, 2000), hlm.11. meninggalkan hawa nafsu, taubat sebagai jalan mendekati Tuhan. Yang keseluruhannya itu mengacu pada unsur etika sufistik.

Sebagaimana dijelaskan di atas bahwa konsep etika sufistik adalah merupakan tipe etika dimana keputusan etikanya berdasarkan pada al-Qur'an, asSunnah, konsep-konsep teologis, kategorikategori filsafat, dan bercorak sufi. Adapun unsur utama dari etika ini biasanya terfokus pada dunia dan manusia. ${ }^{21}$ Etika dalam konsep kehidupan Islam yang disajikan oleh Imam al-Ghazali tak hanya sekedar mendidik ummat Islam menjadi pribadi muslim yang sempurna, tetapi juga sebagai sebuah sarana yang menyatukan hamba bersama tuhannya sehingga tidak ada lagi hijab antara dia dan Allah SWT.

Banyak ahli yang berpendapat bahwa esensi Islam adalah moral, yaitu moral antara seorang hamba dengan Allah, dengan dirinya sendiri, dan dengan orang lain, termasuk dengan anggota masyarakat dan dengan lingkungannya. Moral yang terjalin dalam hubungan antara seorang hamba dengan Allah menegasikan berbagai moral yang buruk, seperti tamak, rakus, gila harta, gila hormat sekalipun, menindas, mengabdikan diri kepada selain Allah (syirik), membiarkan orang yang lemah dan berkhianat.

Sedangkan moral hamba dengan dirinya sendiri melahirkan tindakan positif bagi diri pribadi, seperti menjaga kesehatan jiwa dan raga, menjaga fitrah dan memenuhi kebutuhan-kebutuhan roh dan jasmani. Dengan demikian, krisis spiritual tidak akan terjadi padanya. Dan adapun moral yang terjalin dalam hubungan antara seorang dengan orang lain, menyebutkan keharmonisan, kedamaian dan keselarasan dalam hidup yang dapat mencegah,

${ }^{21}$ Abd. Haris, Etika Hamka Kontruksi Etik Berbasis Rasional Religius (Yogyakarta: LKiS, 2010), hlm. 46. 
mengobati berbagai krisis (spiritual, moral, dan budaya). ${ }^{22}$

Jika moralitas yang menjadi esensi dari agama Islam, maka pada diri nabi Muhammad juga pernah bersabda bahwa seorang mukmin yang sempurna imannya adalah yang paling sempurna moralnya. Hadits lain juga menyebutkan bahwa sesungguhnya misi dari kerasulan Muhammad adalah untuk menyempurnakan akhlak yang mulia. Hadits yang pertama menyiratkan bahwa kesempurnaan iman dan moral adalah dua hal yang saling terkait dan menopang, sedangkan hadits yang kedua mengandung arti kesempurnaan misi kerasulan Muhammad tergambarkan dari kesempurnaan moralitas umat. Jika pemaknaan terhadap dua hadits diatas diselaraskan, maka sesungguhya moralitas Islam adalah gambaran dari tingkat keimanan yang telah dicapai oleh umat.

Dalam Islam, moralitas tidaklah muncul dari ruang hampa dan ia bukanlah hasil dari spekulasi-spekulasi filosof pemikiran manusia. Akan tetapi dalam Islam, moralitas lahir sebagai eksternalisasi sikap-sikap keimanan. Dengan demikian, keimanan menjadi tiang penyangga utama mempertahankan keberlangsungan moralitas tersebut.

Argumen tersebut sebagaimana yang di paparkan oleh seorang tokoh wali kutub Al-Imam Abdullah bin Alawy AlHaddad. ${ }^{23}$ Kesadaran akan kehadiaran Tuhan membuat perilaku para pengikut tasawuf selalu berhati-hati, dan berusaha menjauhi segala sesuatu yang mengundang murka Allah. Seringkali tasawuf diidentifikasi dengan ibsan, adalah tahapan tertinggi yang harus ditempuh oleh

22 Abdul Muhayya, "Peran Tasawuf dalam Menanggulangi Krisis Spritual", Tasawuf dan Kritis (Yogyakarta: Pustaka Pelajar Bekerjasama dengan IAIN Walisongo Press, 2001), hlm. 23-24.

$23 \mathrm{http} / /$ perjalanan sang Hujjatul Islam//www.google.com. diakses pada tgl. 10 Nopember 2020. seorang muslim untuk menuju Tuhan. Dengan demikian tasawuf merupakan intisari dari agama Islam.

Said Aqil Siradj, pakar tasawuf alumnus Universitas Ummul Qura Makkah mengatakan:"Tasawuf sebagai sifat hamba kepada Tuhannya, terhadap dirinya sendiri serta terhadap alam semesta. Disini tasawuf berfungsi sebagai jalan bagi kehidupan. Oleh karena itu, tasawuf Islam datang sebagai dinamisator terhadap spiritualitas Islam. ${ }^{24}$

Dalam buku karya Rosyidi yang berjudul Dakwah Kang Jalal dijelaskan ada tiga dimensi dalam agama Islam yakni syariah, tarikat, dan hakikat. Tiga dimensi tersebut sejajar dengan iman, Islam, dan ibsan. ${ }^{25}$ Sebutan qur'ani yang oleh generasigenerasi muslim belakangan disebut sufisme atau tasawuf adalah ibsan (berbuat kebaikan), suatu kualitas Ilahi dan insane yang banyak disebut dalam al-Qur'an, yang secara khusus menyebutkan bahwa Allah mencintai orang-orang yang mempunyai kualitas ini.

Dengan memahami dimensi-dimensi tasawuf atau lebih mengedepankan aspek batin, dari pada lahiriyah atau dengan menggunakan materi-materi sufisme, yang didalamnya terdapat aspek-aspek yang berhubungan dengan akhlak, baik akhlaq kepada Allah, Rasul, kepada sesama manusia, bahkan akhlak terhadap semua cipataan Tuhan seperti; tawadhu', ikhlas, tasamuh, kasih sayang terhadap sesama dan lain-lain. Dan pada akhirnya agar manusia dapat mendekatkan diri kepada Allah sedekat-dekatnya, memperoleh rahmat dan kasih sayang disisi-Nya.

Dalam salah satu hadits, Nabi Muhammad SAW mendeskripsikan ibsan sebagai dimensi terdalam Islam, setelah Islam dan Iman. Ihsan adalah suatu pengalaman yang terdalam yang dalam kata-kata hadits Nabi, membolehkan kita

24 Rosyidi, Dakwah Sufistik Kang Jalal (Jakarta: Paramadina, 2004), hlm. 13.

${ }^{25}$ Ibid.,hlm. 48 . 
menyembah Allah seakan-akan Dia melihatnya. Ini berarti bahwa tasawuf mengajarkan kepada manusia untuk berusaha keras menyadari akan kehadiran Tuhan dalam alam dan dalam diri manusia itu sendiri. Kesadaran akan kehadiran Tuhan membuat prilaku para pengikut tasawuf selalu berhati-hati, dan berusaha menjauhi segala sesuatu yang mengundang murka Allah. Tasawuf yang diidentifikasikan dengan ibsan, adalah tahap tertinggi yang harus ditempuh oleh seorang muslim untuk menuju Tuhan. Dengan demikian tasawuf merupakan intisari dari agama Islam.

Pandangan al-Ghazali terhadap jalan sufi, setelah mendalami ilmu kalam, filsafat dan bathiniyah, selanjutnya al-Ghazali mendalami ajaran sufi, dengan cara mempelajari kitab-kitab mereka dan berdialog langsung dengan para sufi. Apa yang ia lakukan itu pada akhirnya bukan saja memberikan berbagai pengetahuan tentang jalan tasawuf, tetapi telah mengantarkannya menjadi seorang sufi. Sebab memang bagi seorang sufi yang penting adalah amal, bukan saja ilmu. Namun demikian, sekalipun al-Ghazali menempuh jalan sufi, hal itu tidak membuat membuat beliau meninggalkan syariah dan pemikiran aqliyah, bahkan kedua ilmu tersebut diyakini telah memperkuat keimanan beliau kepada Allah, para Nabi dan hari kiamat. ${ }^{26}$

Dalam hal kesufian, al-Ghazali bukan hanya berteori, tetapi langsung mengamalkan dan mempraktikannya. Menurut pengakuannya, setelah menempuh jalan tasawuf itu, menjadi jelas hakikat kenabian dan khasiatnya atau rahasia-rahasianya. ${ }^{27}$ Seperti diketahui bahwa pada masa sebelum al-Ghazali, ilmu tasawuf telah bercampur dengan anasiranasir dari luar Islam. Dr. Mustafa Helmi

26 Mahfud Masduki, Spritulaitas dan Rasionalitasal-Ghazali (Yogyakarta: TH Press, 2005), hlm. 69.

${ }^{27}$ Ibid.,hlm. 69-70. menerangkan bahwa sumber sufisme telah bercampur aduk dengan faham-faham Hindu (Brahma dan Budha), persi (Mauisme dan Zarathusraisme), Kristen dan falsafah Yunani (Neo Platonisme dan Gnoticisme). ${ }^{28}$

Sudah dijelaskan secara umum bahwa dalam Islam, dalam mengkaji epistemologi terhadap nilai suatu perbuatan seperti yang diuraikan dan diungkapkan oleh George F. Hourani yang mengklasifikasikannya menjadi beberapa aliran, yang salah satunya adalah Objectivisme, ${ }^{29}$ benar memiliki arti yang obyektif. Yaitu suatu perbuatan itu disebut benar apabila terdapat kualitas benar pada perbuatan itu, termasuk dalam aliran ini adalah mu'tazailah dan filosof muslim.

Sehingga epistemologi Objectivisme memunculkan konsep dasar etika sufistik, sehingga penulis angkat dan akan dijelaskan sebagai representasi dari nilainilai etika yang bercorak sufi (sufistik) di dalam kitab Minhaj al-Abidin, yaitu diantaranya adalah: meninggalkan hawa nafsu untuk menuju sang Khaliq yaitu Allah Swt (menuju surga Allah), dan taubat sebagai jalan mendekati Allah Swt.

\section{KRITIK TERHADAP KONSEP ETIKA AL-GHAZALI DALAM KITAB MINHAJ AL-ABIDIN}

Dalam kitab Minhaj al-'Abidin hampir semua isinya yang terkandung di dalamnya terdapat unsur-unsur etika yang bercorak sufistik. Menurut al-Ghazali Etika/akhlak adalah sifat-sifat yang tertanam dalam jiwa yang menibulkan macam-macam perbuatan dengan mudah, tanpa memerlukan pemikiran dan pertimbangan. Secara sederhana, kata khuluq (budi pekerti) dapat berarti suatu

${ }^{28}$ M. Mustafa Hilmi, Hayat al-Rubiyyah fi alIslam (Kairo: Daru Ihya' al-Kutub al-Arabiyyah, 1947), hlm. 31.

${ }^{29}$ George F. Hourani, Reason and Tradition in Islamic Ethics (London: Cambridge University Press, 1985), hlm. 23-25. 
kondisi atau sifat yang merasuk dalam jiwa dan menjadi kepribadian yang melahirkan berbagai perbuatan secara spontan, dengan mudah dan tanpa memrlukan pemikiran dan pertimbangan terlebih dahulu.

Etika sufistik yang digagas oleh alGhazali menjadi kajian yang sangat unik dan menarik ketika di gunakan untuk melihat kondisi kekinian di Indonesia, melihat keterpurukan yang kian melanda disekitar kita tentang etika. Sehingga kajian ini menjadi alat pembantu untuk sedikit menyelesaikan permasalahan yang dialami bangsa.

Namun, perlu kiranya kajian ini akan lebih dipertajam lagi dengan menggunakan metodologi etika sufistik-humanistik yang nantinya akan mengena sampai pada tujuan dari pada etika itu sendiri yaitu bagaiamana seseorang itu menjadi baik dan berbudi pekerti yang baik. Yang menjadi harapan dari bangsa Indonesia itu sendiri yaitu menjadi bangsa yang beradab dan bermartabat tinggi.

\section{SUMBANGAN PEMIKIRAN TEN- TANG ETIKA SUFISTIK TERHADAP KARAKTER MASYARAKAT INDO-NESIA YANG MAJEMUK}

Tidak dapat dipungkiri bahwa kemajuan ilmu dan teknologi, semakin dirasakan oleh semua orang di seluruh belahan bumi ini. Sehingga dunia semakin terasa kecil, semakin mengglobal, dan perubahan terus terjadi dimana-mana di setiap sudut kehidupan. Kondisi ini, sedikit banyak turut memberi pengaruh bagi kehidupan, sehingga diperlukan suatu pegangan yang bersifat abadi agar tidak terseret oleh arus negatif globalisasi dan modernisasi yang mungkin timbul yakni dengan berpegang erat pada agama dan menjalankannya secara terus menerus dalam kehidupan.

Secara garis besar gambaran kehidupan masyarakat saat ini tengah mengalami berbagai pergeseran karena terus berpacu dan bekerja keras memenuhi kebutuhan hidupnya sehingga agama kurang diperhatikan karena selalu berhubungan dengan dunia materialistis. Begitu pula dengan kehidupan sosialnya antar manusia, nyaris hanya dilakukan bila ada kepentingan bisnis atau mendatangkan benefit berupa keuntungan material. Setidaknya dari masalah ini tampak bahwa masyarakat modern sedang mengalami kejatuhan posisinya dari makhluk spiritual menjadi makhluk material. Maka untuk mengembalikan jati diri manusia sebagai makhluk Allah yang paling mulia, manusia harus kembali kejalan Allah dengan kepatuhan pada agama dan dengan melaksanakantugas-tugasnya dengan baik. Hanya dengan cara demikian manusia akan mendapat ketenangan dan kenyamanan sehingga tidak mengalami penyakit frustrasi eksistensial.

Menurut para ahli pemerhati masalah sosial, bahwa ciri-ciri masyarakat modern akan mengalami frustrasi eksistensial yang ditandai dengan keinginan yang berlebihan untuk berkuasa (the will to power), mencari-cari kenikmatan hidup (the will to pleasure), selalu ingin menimbun harta (the will to money), tidak mengenal waktu dalam bekerja sehingga tidak memiliki waktu untuk bersosialisasi (the will to work), serta memiliki kecenderungan libido yang cukup tinggi (the will to sex). Akibat dari penyakit ini, membuat kehidupan menjadi gersang, hampa dan kosong tanpa tujuan sehingga muncullah prilaku negatif seperti kriminalitas, kekerasan, kenakalan, bunuh diri, pembunuhan, hubungan seks diluar nikah, penganiayaan, broken home, perkosaan, kecanduan narkoba, perceraian dan perilaku seks menyimpang dan berbagai macam krisis moral lainnya sebagai dampaknya. ${ }^{30}$

${ }^{30}$ Huston Smith,Kebenaran yang Terlupakan Kiritik atas Sains dan Modernitas, terj. Inyiak Ridwan Muzir (Yogyakarta : IRCiSoD, 2001.), hlm. 130. 
Banyak para ahli yang meratapi zaman ini sebagai abad kejatuhan manusia, karena tidak ditemukannya lagi jiwa masyarakatnya yang bersemi sebagai makhluk Tuhan, karena realitas kehidupan mereka cuma memandang materi dan melupakan agama, meskipun tidak menolak Tuhan dalam bentuk lisan, tetapi mengingkarinya dalam bentuk prilaku. Setiap manusia, bahkan setiap keluarga, tampaknya akan berpapasan dengan problema krisis spiritual. Imbasnya lembaga yang paling banyak merasakan problem itu adalah keluarga, sehingga untuk mengantisipasinya dibutuhkan kecerdasan dan daya tahan keluarga, yakni dengan pendekatan keagamaan dengan mengimani dan menaati segala perintah Allah.

Dengan keimanan dan ketaatan kepada Allah merupakan perbuatan dzikir, sebab makna dzikir itu cukup luas dan termasuk diantaranya pelaksanaan aktifitas yang dilandasi oleh keimanan. Dengan berdzikir seseorang akan mendapatkan ketenangan hati karena memang Allah secara langsung menyebutkan bahwa berdzikir itu mendatangkan ketenangan. Dengan ketenangan atau ketentraman akan memunculkan ketajaman pemikiran dan analisa, yang merupakan bibit yang menumbuhkan kreatifitas. Sebagaimana terungkap dalam sebuah sya'ir Parsi yang mengatakan: "Berdzikirlah sampai dzikirmu menyembulkan fiker, Dan melabirkan seratus ribu pikiran-pikiran murni (andishah)".

Hal lain yang juga telah menjadi karakter manusia modern yang materialistik oriented adalah budaya pragmatisme dan hedonisme. Pragmatisme adalah cara pandang yang melihat sesuatu dari nilai manfaat yang dapat dari sesuatu. Jika ia bermanfaat secara praktis material, maka ia dianggap kebenaran yang bernilai. Demikian juga dengan budaya hedonisme, totalitas kehidupan semuanya diorientasikan untuk sebuah kenikmatan. Kebahagiaan tertinggi adalah karena akumulasi yang banyak dari kenikmatan material, dan sebaliknya kesengsaraan adalah disebabkan manusia tidak menemukan kenikmatan. Motto yang paling terkenal dari kaum hedonis adalah "hidup untuk hari ini". Dari sini dapat diasumsikan bahwa apa saja menjadi legal dan pantas demi sebuah kenikmatan. Pada proses selanjutnya dapat dipastikan bahwa akan terjadi peminggiran terhadap beberapa sisi dari kemanusian itu sendiri, terutama persoalan moralitas juga etika.

Dalam ranah empiris kemudian dapat kita temukan betapa banyak hari ini penyakit-penyakit sosial yang terjadi di masyarakat, mulai dari pelecehan seksual, pemerkosaan, pengkonsumsian obat-obat terlarang, minuman keras, aborsi, perilaku sadisme dan perilaku-perilaku kriminal lainnya yang kesemuanya menghiasi wajah gelap modernitas. Itulah di antara beberapa anomali yang include dalam modernitas itu sendiri dimana kesemuanya ternyata sangat potensial untuk memberangus sisi-sisi eksistensial kemanusiaan.

Sebagai kesimpulan sementara dapat dikatakan, bahwa kemajuan secara kuantitatif material yang dicapai oleh modernitas, tidak diiringi dengan kemajuan kualitatif. Modernitas dengan sederet anomalinya tersebut sedikit banyak telah mengabsurdkan beberapa sisi sejati dari manusia pemujanya. Absurditas ${ }^{31}$ inilah yang selanjutnya menyebabkan manusia modern salah orientasi dalam memaknai hakikat hidup yang ia jalani.

Mengutip survei yang dilakukan Transparency International Indonesia (TII) mendapatkan hasil, rakyat Indonesia berpandangan bahwa parpol dan DPR

31 Absurditas adalah istilah yang sangat melekat pada sosok Albert Camus. Ia menggunakan istilah ini untuk mengambarkan suatu keadaan manusia modern yang tengah mengalami keputusasaan yang disebabkan adanya pemisahan antara dirinya dengan apa yang dilakonkannya. 
merupakan lembaga yang sangat korup. Maka wajar bila parpol merupakan organisasi yang paling bertanggung jawab atas perilaku koruptif. Tingkah laku elit politik saat ini menunjukan kebodohan yang ditunjukan dirinya kepada rakyat, politisi terkesan mengambinghitamkan pemerintah dalam setiap permasalahan hukum, terutama yang berbau korupsi. Kesan ini sengaja ditimbulkan untuk menarik simpatik dari rakyat dan membenci pemerintah. Tujuannya, agar rakyat tidak mempercayai pemerintah dan beranggapan pemerintah telah gagal.

Jika kita merujuk Gustavo Gutiérrez Merino (1971) yang menitik beratkan pada penanaman nilai-nilai etika dalam menjalankan birokrasi. Dirinya, menjelaskan bahwa pendidikan antikorupsi mengharuskan adanya tiga langkah. Pertama, pembebasan politik dan sosial yang mengukuhkan tindak korupsi. Kedua, emansipasi dan partisipasi seluruh masyarakat sebagai korban tindak korupsi untuk membenci dan mengalienasi para koruptor. Ketiga, pembebasan dari egoisme dan dosa dengan mendekatkan Tuhan ke bumi. Etika yang menjunjung tinggi nilai KETUHANAN dalam bertingkah laku didalam menjalankan amanah rakyat. Penanaman etika ini menjadikan sasaran terciptanya sebuah keadilan didalam masyarakat, dengan adanya batasan pemisahan antara penegakan hukum dan kepentingan politik.

Selain bersumber pada sila pertama, Ketuhanan Yang Maha Esa, etika Pancasila juga harus bersumber pada nilainilai sila yang lain. Sebagaimana yang telah dikatakan oleh Mohammad Hatta, wakil presiden pertama Republik Indonesia, bahwa; negara pada hakikatnya adalah berdasarkan atas Ketuhanan Yang Maha Esa serta kemanusiaan yang adil dan beradab sebagai landasan moral yang mewajibkan kepada pelaksana dan penyelenggara negara agar memegang teguh moral Ketuhanan dan Kemanusiaan yang luhur, agar negara tidak terjerumus ke dalam kekuasaan diktator. ${ }^{32}$ Dengan ini jelas bahwa dalam kehidupan kenegaraan terdapat landasan dan dasar-dasar fundamental tentang etika dan moral.

Dari pernyataan tersebut, dapat kita ambil sebuah manfaat untuk membangun Indonesia bebas dari korupsi, diperlukan sebuah etika. Penanaman etika ini bertujuan agar tindakan korupsi tidak dijadikan warisan budaya bangsa. Pemikiran ini, merupakan sebuah langkah yang tepat untuk memperbaiki negeri ini, dalam memerangi korupsi. Jika penanaman etika ini terbentuk, penulis harapkan terciptanya penegakan hukum dan kesejahteraan bagi rakyat. Korupsi yang terjadi selama ini, telah menghancuran sendi-sendi kehidupan, bukan hanya sebatas perekonomian semata, tetapi mampu merubah budaya yang ada di masyarakat.

Berdasarkan uraian di atas, sesungguhnya bangsa Indonesia telah mempunyai pedoman etis yang jika diamalkan maka akan terhindar dari praktik sesuatu perbutan yang bersifat immoral (tidak bermoral). Selain korupsi yang memang menjadi isu besar kita, tetapi praktikpraktik immoralitas yang lain juga perlu diperhatikan. Sehingga kehidupan berbangsa dan bernegara kita akan menjadi tauladan bagi bangsa-bangsa yang lain. Seharusnya ini dimulai dari moralitas para pemimpinya yang tentu saja akan menjadi panutan bagi rakyatnya.

Selain itu, di alam reformasi ini selain supremasi hukum juga perlu supremasi etik, sehingga kita semua dapat hidup damai dan sejahtera. Kesejahteraan inilah yang diimpikan oleh rakyat semua, oleh karena itu pemimpin harus berdasar pada kaidah fiqh: Tasharruf al-imami 'ala al-ra'iyyati manutun bi al-maslahah, artinya

32 Kaelan, Filsafat Pancasila; Pandangan Hidup Bangsa Indonesia (Yogyakarta: Paradigma, 2002), hlm. 142. 
penggunaan kekuasaan oleh seorang pemimpin harus didasarkan atas kemaslahatan rakyatnya. ${ }^{33}$

\section{KESIMPULAN}

Dari beberapa uaraian yang terdahulu dapat ditarik kesimpulan bahwa Etika tasawuf (etika sufistik) merupakan pengejawentahan atau hasil dari sebuah cita-cita dari al-Ghazali itu sendiri yaitu perjalanan terakhir dalam karirnya sebagai seorang pemikir revolusioner dalam mengembangkan kajian keilmuan keIslaman yang mana didalamnya terdapat ada pembahasan pentingnya meninggalkan hawa nafsu dan taubat sebagai jalan spiritualitas bagi manusia. Indonesia sebagai negara pluralistis (sangat majemuk), sebenarnya sudah mempunyai pedoman etis yang jika diamalkan maka akan terhindar dari praktik sesuatu perbutan yang bersifat immoral (tidak bermoral). Selain korupsi yang memang menjadi isu besar kita, tetapi praktikpraktik immoralitas yang lain juga perlu diperhatikan. Sehingga kehidupan berbangsa dan bernegara kita akan menjadi tauladan bagi bangsa-bangsa yang lain. Seharusnya ini dimulai dari moralitas para pemimpinya yang tentu saja akan menjadi panutan bagi rakyatnya. []

33 Al-Suyuthi, Al-Asybah wa al-Nadzair fi al-Furu', (Beirut: Dar al-Kutub al-'Ilmiyah, 2009), hlm. 54.

\section{DAFTAR PUSTAKA}

Abdullah,Yatimin. Studi Akblak dalam Perspektif Al-Qur'an Jakarta: Amzah, 2007.

Ahmad, Zainal Abidin. Riwayat al-Ghazali Jakarta: Bulan Bintang, 1975.

Ghazali, Abu Hamid Al-, Keajaibankeajaiban Hati Bandung: Kanisius, 2000.

Ghazali, Abu Hamid Al-, Minhaj al-Abidin Dar Kutub al-Arabiyyah, Indonesia tt.

Ghazali, Abu Hamid Al-, Teosofia al-Qur'an Surabaya: Risalah Gusti, 1995.

Ghazali, Abu Hamid Al-, Terjemah Minhaj al-Abidin Petunjuk Abli Ibadah Surabaya: Mutiara Ilmu, 1995.

Haris, Abd. Etika Hamka Kontruksi Etik Berbasis Rasional Religius Yogyakarta: LKiS, 2010.

Hilmi, M. Mustafa, Hayat al-Rubiyyah fi alIslam Kairo: Daru Ihya' al-Kutub alArabiyyah, 1947.

Kaelan, Filsafat Pancasila; Pandangan Hidup Bangsa Indonesia Yogyakarta: Paradigma, 2002

Madjid, Nurcholis (ed). Khazanab Intelektual Islam Jakarta: Bulan Bintang, 1994.

Masduki, Mahfud. Spritulaitas dan Rasionalitasal-Ghazali Yogyakarta: TH Press, 2005.

Muhayya, Abdul. "Peran Tasawnf dalam Menanggulangi Krisis Spritual", Tasawuf dan Kritis Yogyakarta: Pustaka Pelajar Bekerjasama dengan IAIN Walisongo Press, 2001.

Rakhmat, Jalaluddin, Meraib Cinta Ilabi Bandung: Rosda Karya, 2000.

Rosyidi, Dakwah Sufistik Kang Jalal Jakarta: Paramadina, 2004.

Smith, Huston. Kebenaran yang Terlupakan Kiritik atas Sains dan Modernitas, terj. Inyiak Ridwan Muzir, Yogyakarta: IRCiSoD, 2001.

Sudin, Filosof Etika dan Sosial Islam Ibn Miskawaih Yogyakarta: SUKA-Press, 2012. 
Syukur, Amin. Masharuddin, Intelektualisme

Tasawnf, Studi Intelektualisme Tasawnf

al-Ghazali Yogyakarta: Pustaka

Pelajar, 2002.

Yahya, Zurkani. Teologi al-Ghazali:

Pendekatan Metodologi, Yogyakarta:

Pustaka Pelajar, 1996. 